\title{
Incidental Bladder Lipoma: A Case Report and Review of the Literature
}

\author{
Tesadüfi Bulunan Mesane Lipomu: Bir Olgu Raporu ve \\ Literatür Derlemesi
}

\author{
José-Fernando VAL-BERNAL', Ainara AZUETA ${ }^{1}$, Roberto BALLESTERO ${ }^{2}$, Javier FUENTES ${ }^{2}$, \\ Alejandro FERNÁNDEZ-FLÓREZ ${ }^{3}$
}

${ }^{1}$ Department of Anatomical Pathology, ${ }^{2}$ Urology Service, and ${ }^{3}$ Diagnostic Radiology Service, University of Cantabria and IDIVAL, Marqués de Valdecilla University Hospital, SANTANDER, SPAIN

\begin{abstract}
Conventional lipoma is the most common benign mesenchymal neoplasm in adults. However, bladder lipoma is a rare tumor. We report an incidental $0.5-\mathrm{cm}$, mucosal, bladder lipoma in a 75 -year-old man, successfully treated with endoscopic excision. The tumor was found during the extension study of a high-grade urothelial carcinoma of the renal pelvis. A review of the published cases, including the present report, yielded a total of 16 . Conclusions on this review are presented. The case is being reported because its rarity and to highlight the importance of complete workup to clarify associated disorders that may suggest extension of a malignant process.
\end{abstract}

Key Words: Lipoma, Urinary bladder neoplasms

\section{ÖZ}

Lipom erişkinlerde en sık rastlanan benign mezenkimal neoplazidir. Ancak, mesanede nadiren izlenir. Burada, 75 yaşında erkek hastanın mesanesinde saptanan ve endoskopik eksizyon ile tedavi edilen 0,5 $\mathrm{cm}$ çapında bir lipom sunulmaktadır. Tümör, renal pelvis yerleşimli yüksek dereceli ürotelyal karsinom nedeni ile yapılan tarama sırasında saptanmıştır. Literatürde olgumuzla birlikte yayınlanmış olan olgu sayısı 16'dır. Olgumuz, nadir olduğu için ve ayrıntılı ve tam bir taramanın malignitelerden ayırımının yapılabilmesi için önemli olduğunu vurgulamak amacı ile sunulmaktadır.

Anahtar Sözcükler: Lipom, Mesane tümörleri

\section{INTRODUCTION}

Conventional lipomas are the most common benign mesenchymal neoplasms in adults. They occur mostly in persons after the age of 40 with a male predominance (1). Most lipomas are superficial, and deep or visceral lipomas are uncommon. These deep or visceral lipomas are often discovered at a late stage of development and consequently tend to be larger than superficial lipomas.

The most frequent benign mesenchymal tumor in the urinary bladder is leiomyoma. Bladder lipomas are rare tumors. As far as we are aware, only 15 cases of this neoplasm have been documented (2-16). We report herein a small mucosal lipoma of the bladder incidentally discovered during cystoscopy. Besides, a review of the literature on this subject is presented.

\section{CASE REPORT}

A 75-year-old man was referred to the urology service for surgical treatment of a $3-\mathrm{cm}$, high-grade urothelial

(Turk Patoloji Derg 2015, 31:64-67)

Received : 07.08.2014 Accepted : 02.09.2014 carcinoma of the left renal pelvis. Past medical history was insignificant. A radical left nephroureterectomy was performed. Computerized tomography (CT) scan demonstrated a $0.3 \times 0.3 \mathrm{~cm}$ round, fat density filling defect in the bladder dome (Figure 1A,B). During cystoscopic examination, a smooth, yellow-colored, well-circumscribed, submucosal polyp measuring $0.7 \times 0.6 \times 0.4 \mathrm{~cm}$ within the dome of the bladder was detected. Transurethral resection of the entire lesion was performed and sent for histopathological examination.

Microscopic study demonstrated a well-circumscribed, ovoid, expansile nodule of mature adipose tissue located within the lamina propria of the mucosa layer without any evidence of malignancy or bladder wall invasion (Figure 2). The lesion was covered by a thin rim of urothelial mucosa (Figure 3). The maximum diameter of the fat lesion was 0.5 $\mathrm{cm}$.

The patient had an uneventful recovery during the postoperative follow-up period.

Correspondence: José-Fernando VAL-BERNAL

Department of Anatomical Pathology, University of Cantabria and IDIVAL, Marqués de Valdecilla University Hospital, SANTANDER, SPAIN

E-mail: apavbj@humv.es Phone: +34 942 202520; ext: 73232 

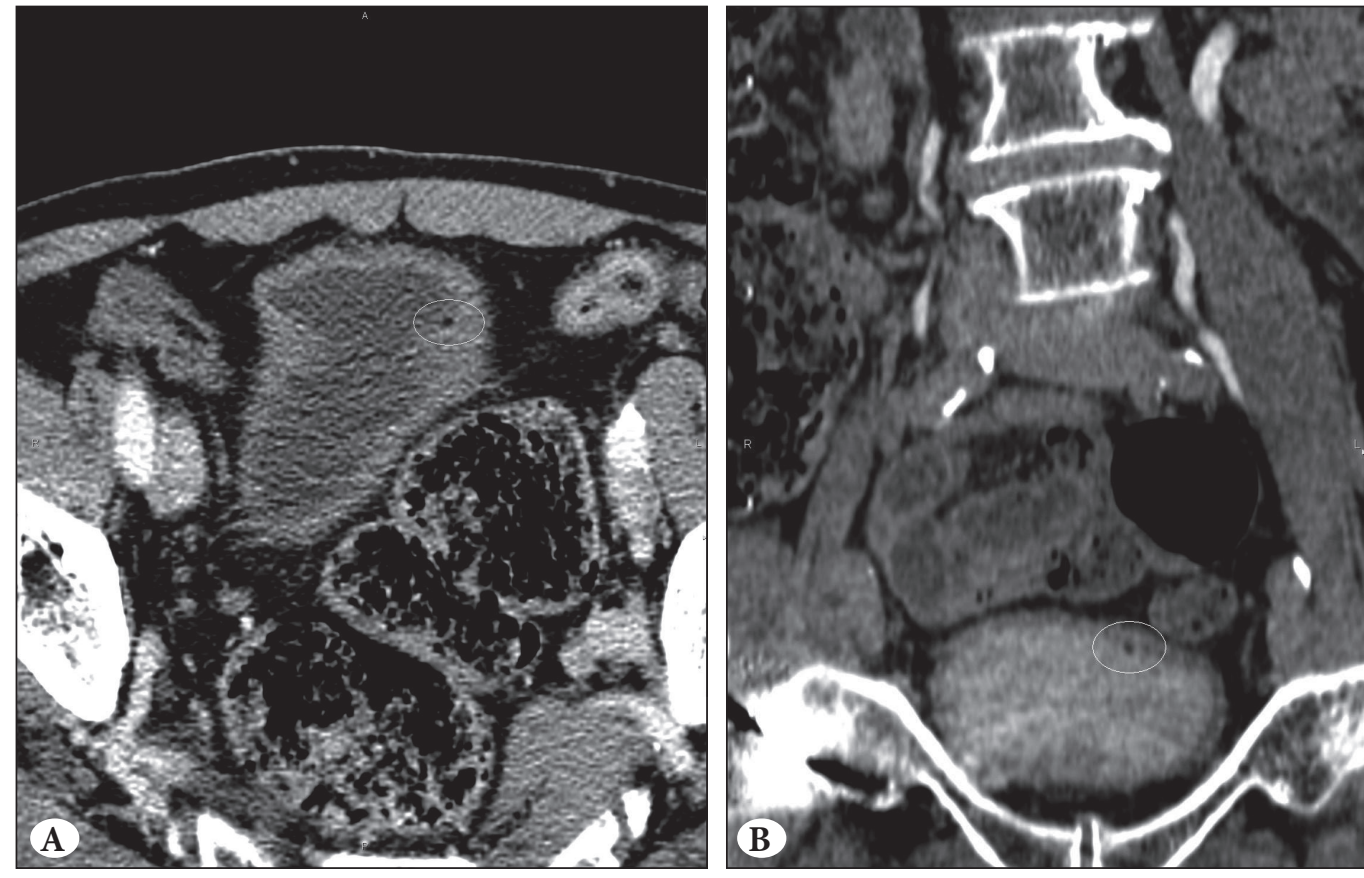

Figure 1: Contrast-enhanced abdominal computerized tomography (CT). A tiny hypodense lesion in the inner right surface of the bladder dome can be seen. It is a $0.3 \mathrm{~cm}$ tumor with negative Hounsfield values (-22 units) consistent with the fatty nature of the lesion demonstrated in the white circle in (A) axial CT image in portal phase, and (B) coronal multiplanar reconstruction in excretory phase scan image.

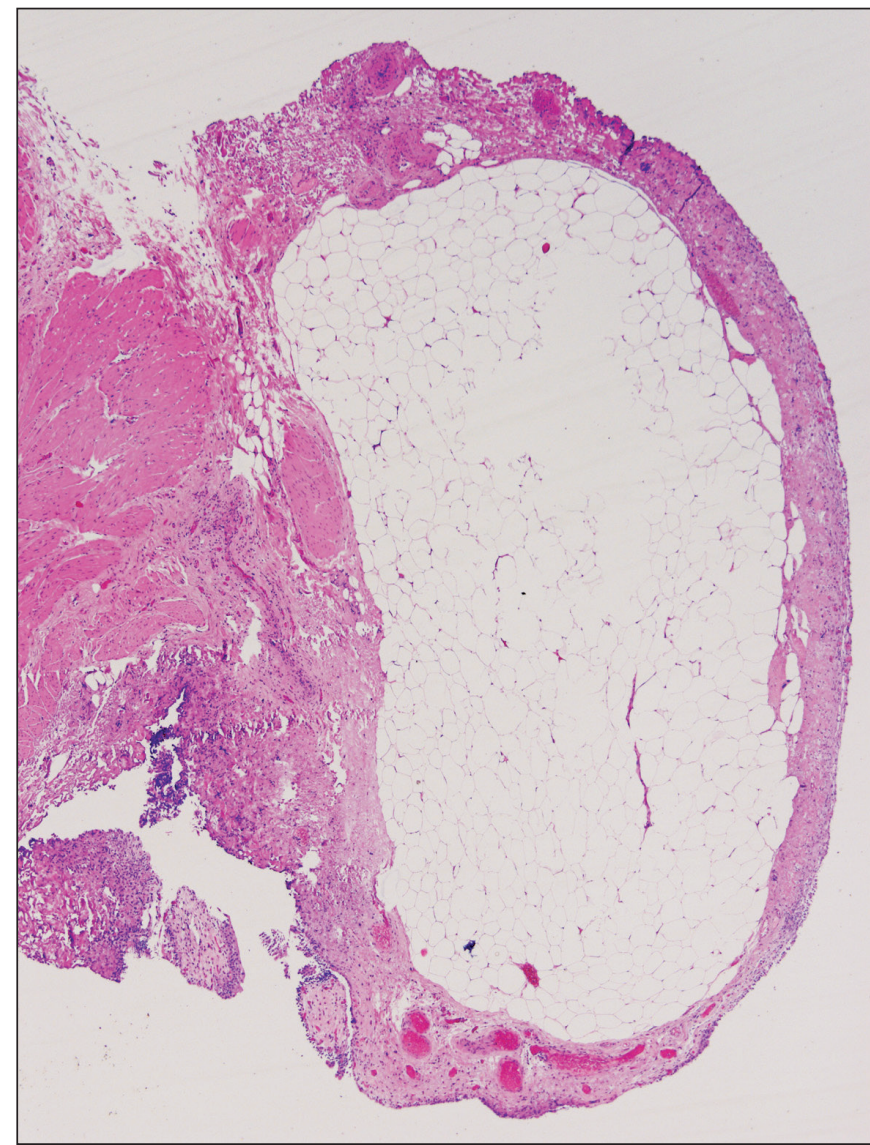

Figure 2: Histopathology of the bladder lipoma. Panoramic microscopic view of the specimen showing a well-circumscribed, rounded neoplasm composed of mature fat cells located in the lamina propria (H\&E; x16).

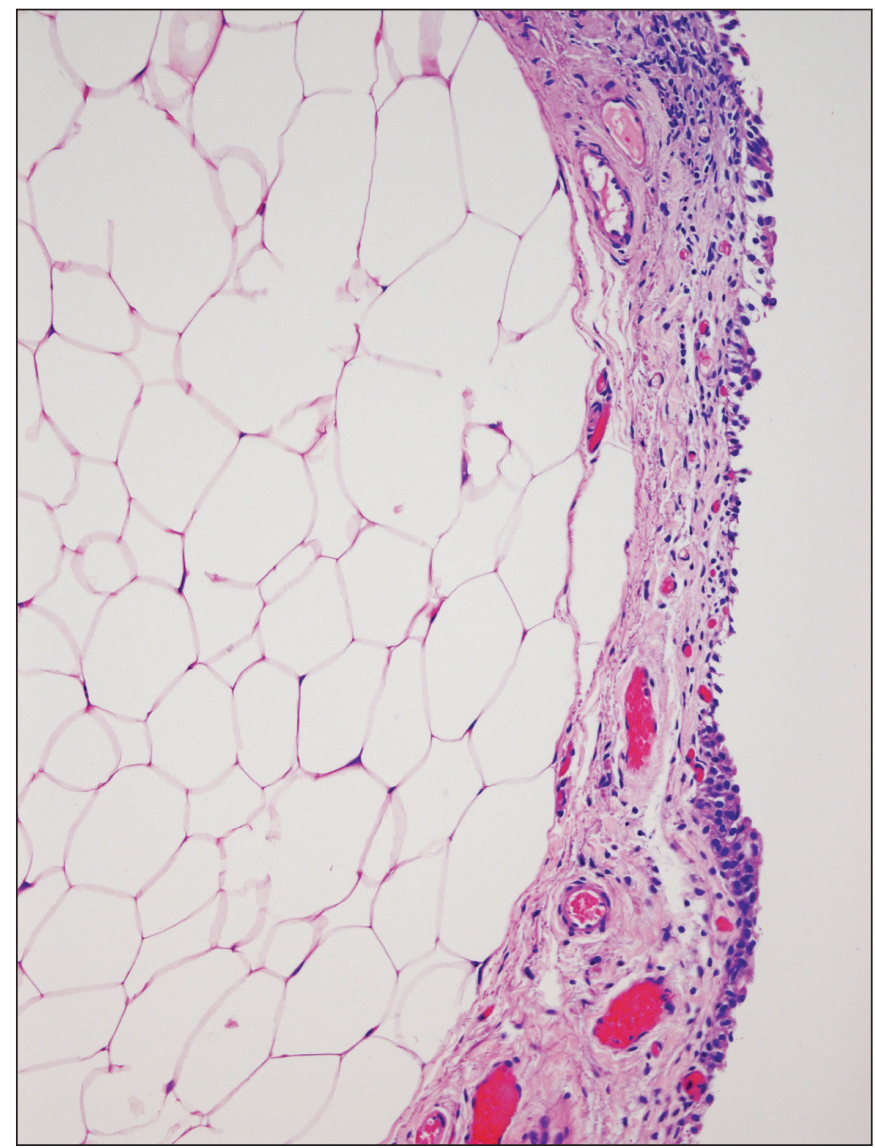

Figure 3: Higher power view of the specimen. A thin rim of urothelial mucosa is covering the neoplasm consisting of univacuolar adipocytes without atypia (H\&E; x25). 


\section{DISCUSSION}

Lipomas are usually asymptomatic, slow-growing, nontender, round masses with soft consistency. Deep visceral lipomas may cause a variety of symptoms depending of their site and size.

Bladder lipoma is rare. A review of published cases of bladder lipoma, including the present report, yielded a total of 16 (Table I). The mean age of these patients at presentation was 56.2 years (SD, 12.4 ; range, 32-75 years). Nine (56.2\%) patients were male. The lesion can show endophytic or exophytic, and sessile or pedunculated growth. All tumors had a yellowish color.

Most tumors were endophytic in mucosa or submucosa. Attenuation coefficient of these lesions in Hounsfield units indicates lipomatous tissue by CT. Cystoscopy findings were very suggestive. In these cases transurethral resection was performed to achieve histologic confirmation. These tumors were small and most of them (59.1\%) measured less than $2 \mathrm{~cm}$. Exophytic neoplasms can be very large
$(2,13)$ and they may present as a retroperitoneal mass (13). Lipomas were located in every site of the bladder and most of them were covered by urothelial mucosa. Seven (36.8\%) cases were located in the posterior wall and $5(26.3 \%)$ in the fundus or dome. They may present with hematuria, urinary frequency, nocturia, urinary tract infection, or as a retroperitoneal mass. The most common presentation (56.2\%) is asymptomatic gross or microscopic hematuria. The bleeding can be attributed to excoriations of the mucosa over the lipoma. The neoplasm was incidentally observed in $3(18.7 \%)$ of cases. In 4 (25\%) cases the patients had multiple lipomas.

Microscopically, lipomas were well-circumscribed, expansile neoplasms composed of mature adipose tissue. The voluminous tumor described by Sederl was a fibrolipoma (2).

Differential diagnosis of bladder lipoma includes welldifferentiated liposarcoma, pelvic lipomatosis, and urachal fibrolipoma. Well-differentiated liposarcoma shows marked variation in adipocyte size, nuclear hyperchromasia,

Table I: Bladder lipomas: Review of the literature

\begin{tabular}{|c|c|c|c|c|}
\hline Case No./Reference & Age (years)/Sex & Location & $\begin{array}{c}\text { Maximum size } \\
(\mathrm{cm})\end{array}$ & Presentation \\
\hline 1. Sederl J. (2) & 43/Female & $\begin{array}{c}\text { Fundus } \\
\text { Posterior wall }\end{array}$ & $\begin{array}{l}20 \\
3.5\end{array}$ & $\begin{array}{c}\text { Colicky pain when } \\
\text { urinating }\end{array}$ \\
\hline 2. Kracht H. (3) & 72/Female & Posterior wall & Not reported & Gross hematuria \\
\hline 3. Zajaczkowski T. (4) & 54/Male & Fundus & 4.5 & Incidental \\
\hline 4. Alonso Gorrea M., et al. (5) & 72/Female & Fundus & 0.40 & Incidental \\
\hline 5. Eggener SE, et al. (6) & 53/Male & Posterior wall & 1.3 & Microscopic hematuria \\
\hline 6. Ulker V, et al. (7) & 32/Male & $\begin{array}{c}\text { Left posterolateral } \\
\text { wall }\end{array}$ & 0.69 & Microscopic hematuria \\
\hline 7. Meraj S, et al. (8) & 53/Male & Posterior wall & Not reported & Microscopic hematuria \\
\hline 8. Kunkle DA, et al. (9) & 48/Male & $\begin{array}{c}\text { Anteroinferior and } \\
\text { left lateral wall }\end{array}$ & Not reported & $\begin{array}{c}\text { Urinary frequency and } \\
\text { nocturia }\end{array}$ \\
\hline 9. Lang EK. (10) & 73/Male & Trigone & Multiple 0.7-1 & Gross hematuria \\
\hline 10. Lang EK. (11) & 54/Male & Trigone & Cluster of $0.6-0.8$ & $\begin{array}{l}\text { Recurrent gross and } \\
\text { microscopic hematuria }\end{array}$ \\
\hline 11. Brown C, et al. (12) & 44/Male & Dome & Not reported & Urinary tract infection \\
\hline 12. Ukita S, et al. (13) & 61/Female & Not reported & 15.0 & Gluteal pain \\
\hline 13. Harisinghani MG, et al. (14) & 46/Female & Posterior wall & Not reported & Hematuria \\
\hline 14. Tsui JF, et al. (15) & 61/Female & $\begin{array}{l}\text { Anterior wall } \\
\text { Left lateral wall }\end{array}$ & $\begin{array}{l}1.2 \\
0.8\end{array}$ & $\begin{array}{l}\text { Urgency and urge } \\
\text { incontinence. } \\
\text { Microscopic hematuria }\end{array}$ \\
\hline 15. Akan S, et al. (16) & 59/Female & $\begin{array}{c}\text { Right } \\
\text { posterolateral wall }\end{array}$ & 1.5 & $\begin{array}{l}\text { Hematuria,and urge } \\
\text { incontinence }\end{array}$ \\
\hline 16. Present report & 75/Male & Dome & 0.5 & Incidental \\
\hline
\end{tabular}


scattered lipoblasts, and bizarre multinucleated stromal cells. Pelvic lipomatosis is characterized by massive overgrowth of mature adipose tissue in the perivesical and perirectal portions of the pelvic retroperitoneum. The fat tissue causes external compression of the lower urinary tract and rectosigmoid colon. The patients complain of perineal or lower abdominal pain, increased urinary frequency, hematuria and constipation. The fatty growth is diffuse rather than nodular (17). The urachus, which extends from the umbilicus to the apex of the bladder, involutes shortly after birth becoming a fibrous cord called the median umbilical ligament. Though rarely, a calcified fibrolipoma may appear in this structure (18). Bladder lipomas behaved as benign tumors with no recurrences.

In conclusion, lipoma is a rare finding within the bladder wall. The most common presentation is asymptomatic hematuria. The tumor may be incidentally found during the clinical search for another process. Most tumors were endophytic, yellowish, located in mucosa/submucosa, and measured less than $2 \mathrm{~cm}$. CT density and cystoscopic observation suggest benign adipose tissue. All reported cases behaved as benign lesions and did not show recurrences.

\section{REFERENCES}

1. Myhre-Jensen O. A consecutive 7-year series of 1331 benign soft tissue tumors, Clinicopathologic data. Comparison with sarcomas. Acta Orthop Scand. 1981;52:287-93.

2. Sederl J. An unusual tumor of the urinary bladder. Zentralbl Gynakol. 1957;79:438-44.

3. Kracht H. Lipoma of the urinary bladder mucosa. Z Urol Nephrol. 1966;59:269-72.

4. Zajaczkowski T. Lipoma of the bladder. Pol Przegl Chir. 1976;48:301-3.

5. Alonso Gorrea M, Tramoyeres Celma A, Pastor Sempere F, Santolaya García I, Gallego Gómez J, Jordá Cuevas M, Mompo Sanchís JA. Bladder lipoma: Apropos of a case. Arch Esp Urol. 1982;35:381-3.
6. Eggener SE, Hairston J, Rubenstein JN, Gonzalez CM. Bladder lipoma. J Urol. 2001;166:1395.

7. Ulker V, Gunhan M, Vural G, Dal H. Lipoma of the urinary bladder. BJU International. 2001;88:644.

8. Meraj S, Narasimhan G, Gerber E, Nagler HM. Bladder wall lipoma. Urology. 2002;60:164.

9. Kunkle DA, Mydlo JH. Bladder wall lipoma in patient with irritative voiding symptoms. Urology. 2005;66:653-4.

10. Lang EK. Symptomatic bladder lipomas. J Urol. 2005;174:313.

11. Lang EK. Recurrent macroscopic and microscopic hematuria with lipoma at the trigone of the bladder. J Urol. 2005;174:724.

12. Brown C, Jones A. Bladder lipoma associated with urinary tract infection. Scientific World Journal. 2008;8:573-4.

13. Ukita S, Koshiyama M, Ohnaka M, Miyagawa N, Yamanishi Y, Nishimura F, Nagura M, Kim T, Hirose M, Shirase T, Kobayashi $\mathrm{H}$, Ozasa H. Retroperitoneal lipoma arising from the urinary bladder. Rare Tumors 2009;1:e13.

14. Harisinghani MG, Mueller PR: Teaching atlas of abdominal imaging, case 124. New York: Thieme Medical Publishers Inc; 2009.

15. Tsui JF, Weinberger JM, Kashan M, Weiss JP, Robinson BD, Blaivas JG. Bladder lipoma. J Urol. 2013;190:1387-8.

16. Akan S, Yüksel Ö, Özbay N, Uruc F, Verit A. A rare entity of benign bladder neoplasm: Female lipoma. Georgian Med News. 2014;228:17-20.

17. Klein FA, Smith MJ, Kasenetz I. Pelvic lipomatosis: 35-year experience. J Urol. 1988;139:998-1001.

18. Willson TD, Revesz E, Podbielski FJ, Connolly MM. Unusual findings in a benign urachal tumor. Am Surg. 2013;79:E76-7. 